\title{
Redescription of Chrysidea pumiloides Zimmermann, 1956, and description of three new species of Chrysidea from Madagascar (Hymenoptera: Chrysididae)
}

\author{
Toshiharu MITA $^{1, *} \&$ Paolo ROSA ${ }^{2}$ \\ ${ }^{1}$ Faculty of Agriculture, Kyushu University, Motooka 744, Nishi-ku, Fukuoka-shi, 819-0395 Japan. \\ ${ }^{2}$ Via Belvedere 8/d, I-20881 Bernareggio (MB), Italy. \\ *Corresponding author: t3mita@agr.kyushu-u.ac.jp \\ ${ }^{2}$ Email: rosa@chrysis.net \\ ${ }^{1}$ urn:1sid:zoobank.org:author:6CC49F2C-C91C-463C-9C2D-8269588E1A6A \\ ${ }^{2}$ urn:1sid:zoobank.org:author:F1E8DF8A-6105-4AC8-96F9-31EDA674D320
}

\begin{abstract}
Chrysidea pumiloides Zimmermann, 1956 and its Malagasy allies are taxonomically revised. As a result, C. pumiloides and C. phoebe Zimmermann, 1956 are redescribed; two new species, C. vazimba sp. nov. and C. merina sp. nov., are described from museum collections, and another new species, C. rioae sp. nov., is described based on a male recently collected in Southern Madagascar, at Berenty Reserve. The habitus of the holotypes and the male genitalia are illustrated and the key to Malagasy Chrysidea Bischoff, 1913 is updated.
\end{abstract}

Keywords. Key to species, parasitoid, male genitalia, museum collection, taxonomy.

Mita T. \& Rosa P. 2019. Redescription of Chrysidea pumiloides Zimmermann, 1956, and description of three new species of Chrysidea from Madagascar (Hymenoptera: Chrysididae). European Journal of Taxonomy 564: 1-20. https://doi.org/10.5852/ejt.2019.564

\section{Introduction}

Chrysidea Bischoff, 1913 (Hymenoptera, Chrysididae) is a small genus comprising 22 species (Kimsey \& Bohart 1991; Rosa \& Xu 2015). It is known from Africa to Eurasia, yet 13 species are endemic to Madagascar (Azevedo et al. 2010). Malagasy species were taxonomically revised by Zimmermann (1956, 1961) and Bohart (1988), who described two new species and provided an identification key. They are considered as parasitoid of Sphecidae and Crabronidae sensu Sann et al. (2018) (Zimmermann 1961; Kimsey \& Bohart 1991), but their biology is poorly known. Recently, Pauli et al. (2019) indicated the polyphyly of Chrysis Linnaeus, 1761 based on molecular data. They discussed that a genus-level reclassification is needed among Chrysis and related genera, including Chrysidea. Although it is difficult to define the genus Chrysis because of its great variation, Chrysidea is well recognized from Chrysis by the modified head, in front view with a bulging brow and a short and deep scapal basin, thus making the head somewhat transversely oval in lateral view; the gena with two carinae; discoidal cell of 
forewing with outer veins nearly nebulous in most species. Chrysidea is also recognized from Trichrysis Lichtenstein, 1876, sister to Chrysidea, by TFC topping scapal basin; discoidal cell of forewing with outer veins usually nebulous; S2 black spots distinctly separated with each other, etc. (Rosa et al. 2016).

Chrysidea pumiloides Zimmermann, 1956 was described based on the holotype and a paratype from Bekily, Madagascar (Zimmermann 1956). It is peculiar among Malagasy species because it lacks a transverse frontal carina (TFC) on frons. In the course of our study of Chrysididae in museum collections, clearly different species with distinct TFC were found among specimens previously identified as C. pumiloides. A female deposited in the Zimmermann collection at the Naturhistorisches Museum (Vienna, Austria) has a red label "TYPE" handwritten by Zimmermann himself; it was considered to be the holotype or, at least, a specimen of the type series. However, this female has a distinct TFC and its collection site is incongruent with the original description. Therefore, this female specimen should be non-type material even it bears the type label, as well as other specimens of Zimmermann observed in his collection (Rosa et al. in preparation). Actually, the true holotype is deposited at the Muséum national d'Histoire naturelle (Paris, France) as mentioned in the original description (Zimmermann 1956). It is easy to suppose that the presence of an erroneous type and its wrong identification lead to confusion for subsequent researchers. In fact, some identifications made by Linsenmaier and Bohart included different species related to $C$. pumiloides. The key of Bohart (1988) to Malagasy species did not mention the missing TFC of C. pumiloides, a unique feature in this species, shared only with C. asensioi Mingo, 1985 in the West Palaearctic; it was not even mentioned in the generic diagnosis of Kimsey \& Bohart (1991). A taxonomic revision of historical collections and recently discovered specimens resulted in the discovery of three new species described and illustrated here.

\section{Material and methods}

Terminology follows that of Kimsey \& Bohart (1991) and Rosa \& Xu (2015). Male terminalia were dissected, placed in $\mathrm{KOH}(10 \%)$ and boiled for ten minutes. They were observed under a Hitachi S 3000N scanning electron microscope (Hitachi, Tokyo, Japan). Label data for historical specimens are transcribed as written on the paper card. Labels are separated from each other by quotation marks and a single slash was used for line feed. The key to Malagasy Chrysidea was made based on our observations and those of Bohart (1988).

\section{Repositories}

ELKU = Entomological Laboratory, Faculty of Agriculture, Kyushu University, Fukuoka, Japan

MNHN = Muséum national d'Histoire naturelle, Paris, France (C. Villemant and A. Touret-Alby)

NHMW $=$ Naturhistorisches Museum, Vienna, Austria (D. Zimmermann)

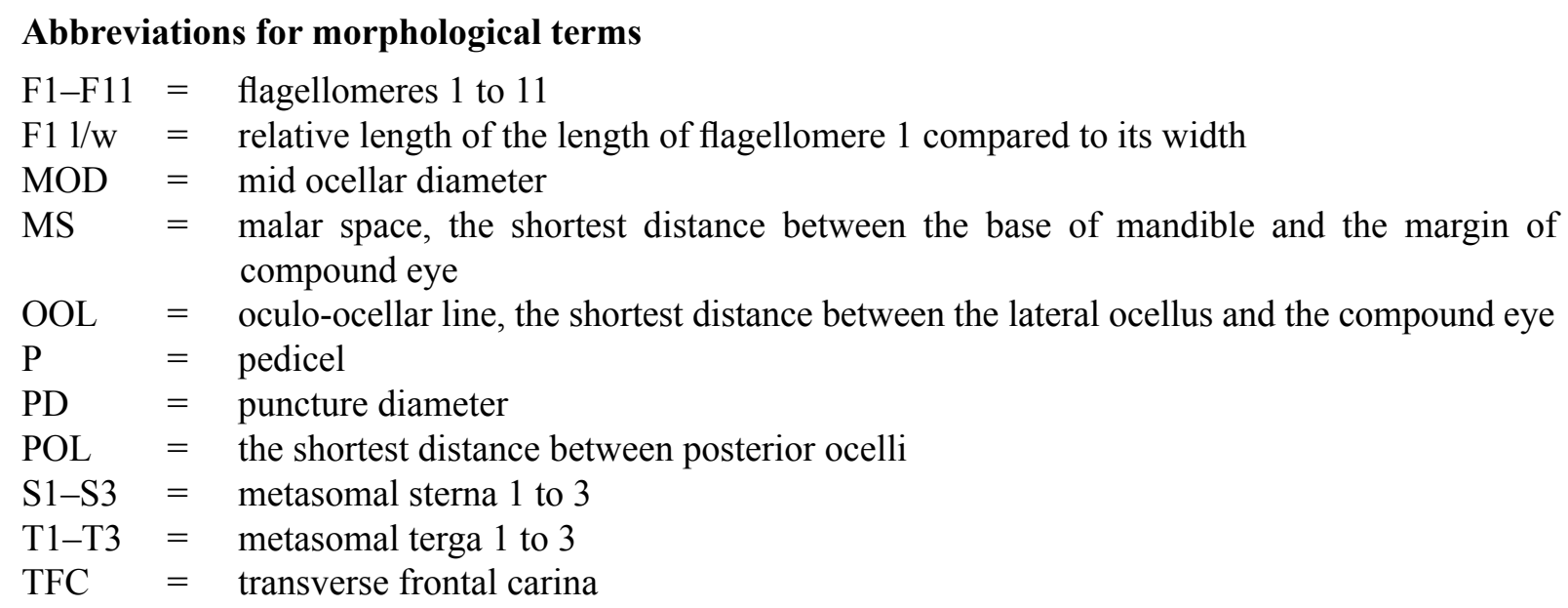




\title{
Results
}

\section{Species description}

\author{
Class Insecta Linnaeus, 1758 \\ Order Hymenoptera Linnaeus, 1758 \\ Superfamily Chrysidoidea Latreille, 1802 \\ Family Chrysididae Latreille, 1802 \\ Subfamily Chrysidinae Latreille, 1802 \\ Genus Chrysidea Bischoff, 1913
}

Chrysidea pumiloides Zimmermann, 1956

Figs 1-2, 9A

Chrysidea pumiloides Zimmermann, 1956: 148.

Chrysidea pumiloides - Zimmermann 1961: 306 (catalog). — Bohart 1988 (key, partim). — Kimsey \& Bohart 1991: 314 (catalog). — Madl 2008: 83 (catalog). — Azevedo et al. 2010: 860 (catalog, partim).

\section{Material examined}

\section{Holotype}

MADAGASCAR • O; "MNHN, Paris/EY25666"; "Madagascar: Bekily/IV-1942/A. Seyrig"; "Chrysidea / pumiloides Zimm./det. Zimmermann/Type! [handwritten by Zimmermann]"; "MUSÉUM PARIS"; "O Chrysidea pumiloides/Zimmermann/Holotype [handwritten by Bohart on red card]"; MNHN.

\section{Other material}

MADAGASCAR • 1 \%; "MADAGASCAR/Behara"; "MUSEUM PARIS / XI 38 / A. SEYRIG”; NHMW - 1 \%; "Antsingy N., $63 \mathrm{~km}$. Est/Inst. Scient. Madagascar/Maintirano forêt/VII-49 RP"; "TYPE"; "Chrysis L. + / Chrysidea/planipunctata/Type Lins. 53/Linsenmaier det.”; "=C. pumiloides Zimm. F. Strumia"; MNHN• 4 qo, 1 ○ึ; "Madagascar, No. 66”; ELKU.

\section{Diagnosis}

Chrysidea pumiloides is characterized by the combination of the following characters: TFC absent; head wide, 1.3-1.4 $\times$ as wide as high; distal margin of T3 with large, triangular lateral teeth and area between rounded; MS $=0.6-0.8 \mathrm{MOD}$; tegula brown with more or less strong blue to purple reflection; mesoscutellum with impunctate area; metanotum rounded, without anteromedian pit; T2 with microreticulate interspaces among punctures; male genitalia with distal apex of paramere flat.

\section{Description}

\section{Female}

BODY LENGTH. 3.8-4.8 mm.

HEAD. Width $1.3-1.4 \times$ as wide as high. Scapal basin deep, transversely wrinkled and punctate with sparsely located minute punctures. TFC absent (Fig. 1B). Antennomeres P, F1, F2, F3 in the following proportions: $1.2-1.7,1.0-1.8,0.7-1.0,1.0-1.2 ; \mathrm{F} 1 \mathrm{l} / \mathrm{w}=1.5-1.9 ; \mathrm{OOL}=1.3-1.5 \mathrm{MOD} ; \mathrm{POL}=1.7-1.9$ MOD; MS = 0.6-0.8 MOD; apical margin of clypeus slightly concave; mandible edentate; basal width of mandible $=1.1 \mathrm{MOD}$. Brow and vertex punctate-reticulate; punctures on brow irregular and slightly larger, PD: 0.5-0.6 MOD (Fig. 1B). 
Mesosoma. Pronotal groove shallow and indistinct, extending $2 / 3-3 / 4$ length of pronotum. Notauli deep, complete; parapsidal lines indicated by smooth strip. Mesoscutellum almost flat. Metanotum rounded, separated from mesoscutellum by deep furrow, large anteromedian pit absent. Pronotum, mesoscutum and metanotum densely punctate, almost punctate-reticulate: punctuation on surface between notauli sparser, 0.2-0.5 PD apart in a female labeled "No. 66" (ELKU); base of punctures flat, margin keenly edged; mesoscutellum densely or sparsely punctate, dorsal surface with smooth impunctate area (Fig. 1C): smooth area narrower in a female from Antsingy (MNHN). Episternal sulcus and scrobal sulcus distinct, formed by large foveae. Metanotum without anteromedian pit, rounded in lateral view. Forewing weakly infuscate with discoidal cell incomplete, outer veins not pigmented (Fig. 1A).

Metasoma. Median line absent or faintly present on T1 and T2 (Fig. 1D). Punctures on T1 0.2-0.4 MOD, almost punctate-reticulate with smooth interspaces; punctures on T2 and T3 smaller, sometimes indistinct, $0.15-0.3 \mathrm{MOD}$, with granulate interspaces: interspaces almost smooth, only faintly granulate in a female from Antsingy (MNHN); pre-pit row area of T3 weakly bulged; pit row distinct, with deep

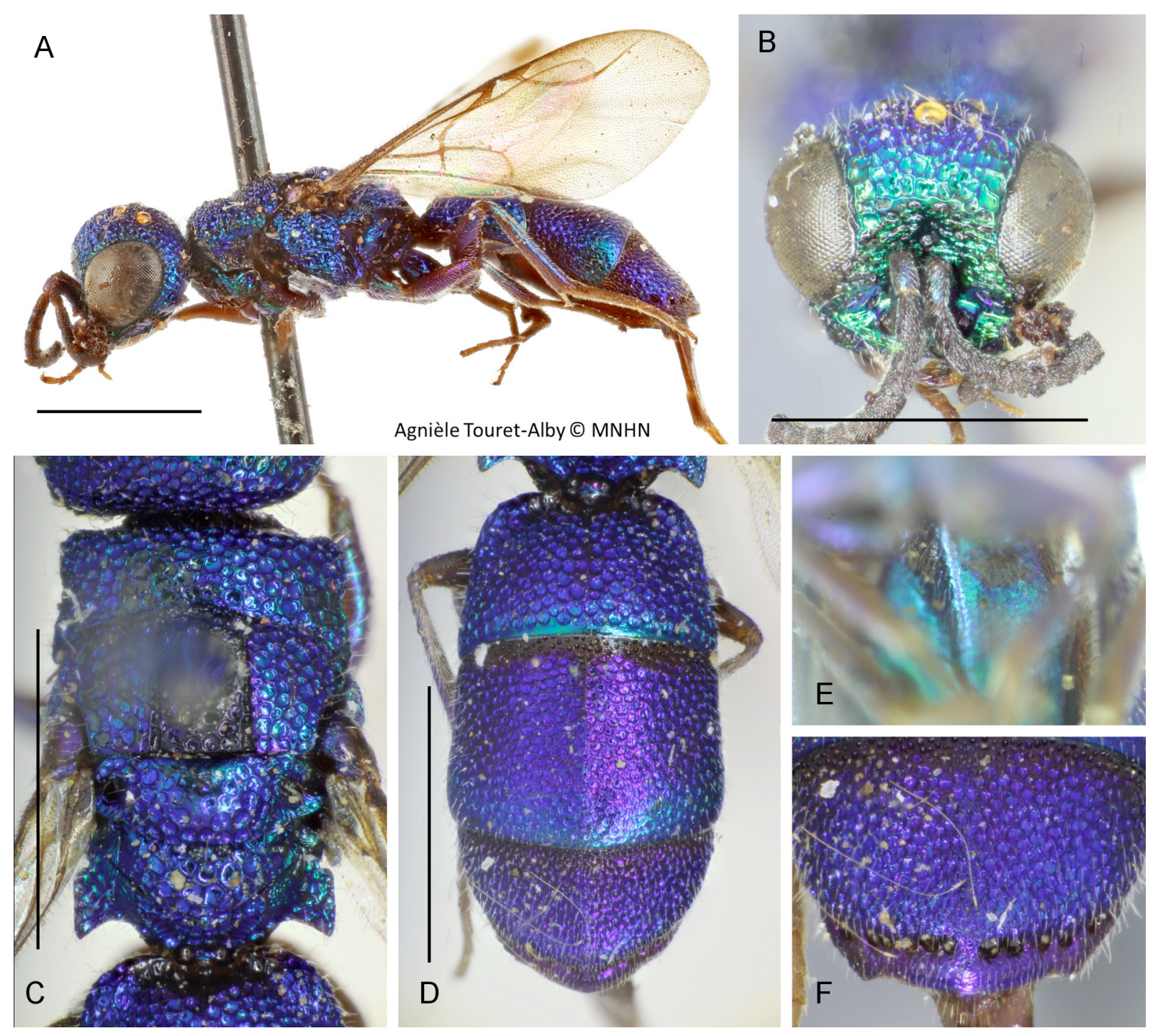

Fig. 1. Chrysidea pumiloides Zimmermann, 1956, holotype, q. A. Lateral habitus. B. Head. C. Mesosoma. D. Metasoma. E. Black spots on S2. F. T3. Scale bars $=1.0 \mathrm{~mm}$. 
pits. Apex of T3 with a pair of lateral dully teeth, interval between teeth rounded (Fig. 1F). S2 (Fig. 1E) black spots oval and medially separated by $0.8 \mathrm{MOD}$.

Coloration. Head metallic blue-green to blue, sometimes purplish, face more greenish. Antenna dark brown with scape, pedicel, F1 and F2 metallic blue-green or blue: F1 and F2 of holotype almost dark brown. Mandible testaceous, basal 1/3 metallic blue-green, apex reddish dark brown. Mesosoma metallic blue-green, sometimes surface between notauli darkened: surface of holotype blackish with purplish luster. Tegula brown with strong purple reflection; reflection weaker, more brownish in smaller specimens and more bluish in female from Antsingy. Legs brown, with strong purplish reflection and green luster on coxae and femora: hindcoxa of a female from Behara (NHMW) metallic green; tibiae brown with greenish reflection, sometimes bluish; tarsi brown. T1 metallic blue-green, sometimes purplish, more greenish laterally and posteriorly; T2 metallic blue with purplish luster, greenish or bluish without purplish luster laterally and posteriorly; T3 metallic purple, bulged pre-pit row area usually bluish. Sterna metallic blue-green to green.
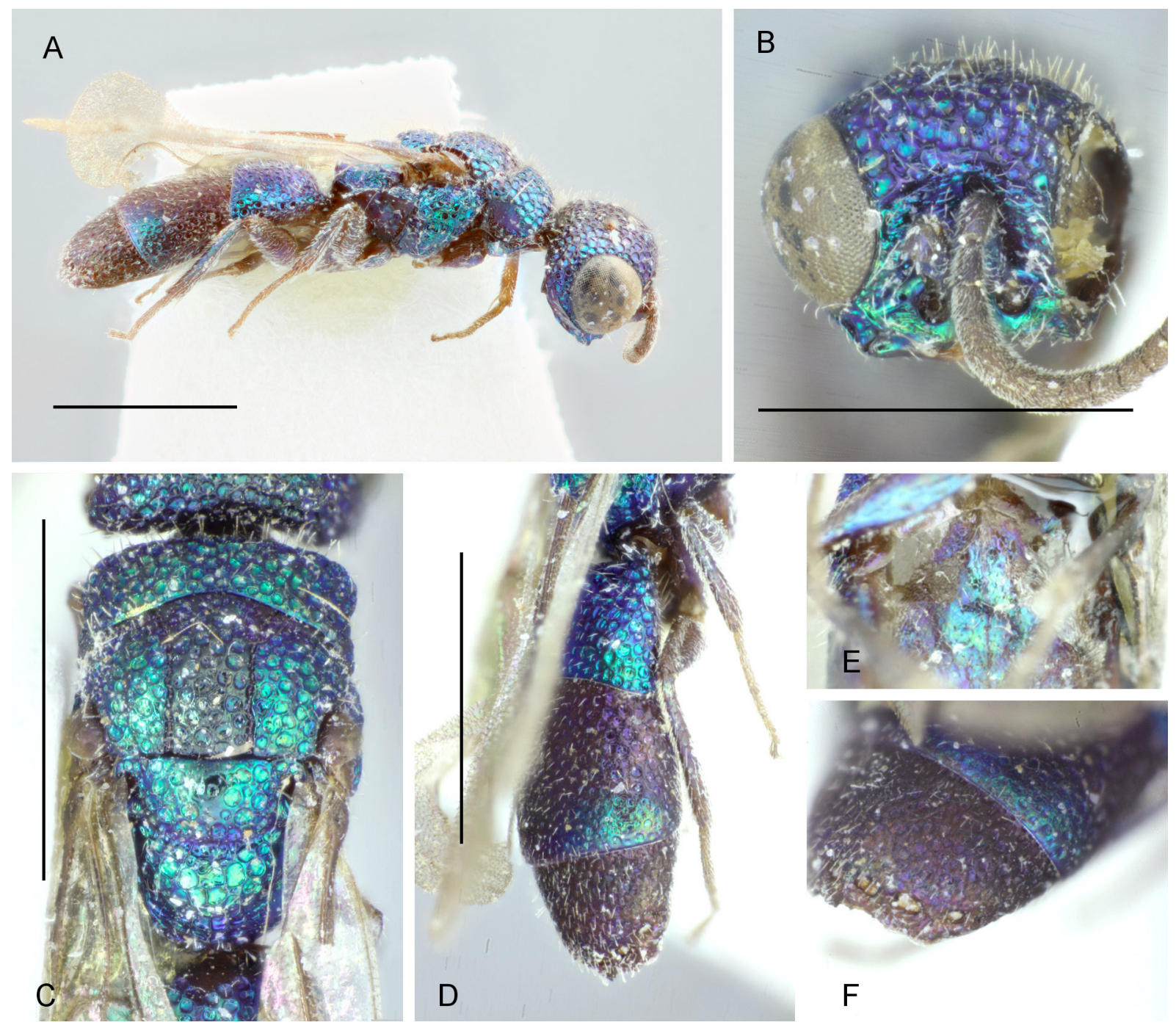

Fig. 2. Chrysidea pumiloides Zimmermann, 1956, O. A. Lateral habitus. B. Head. C. Mesosoma. D. Metasoma. E. Black spots on S2. F. T3. Scale bars $=1.0 \mathrm{~mm}$. 


\section{Male}

Body length $3.0 \mathrm{~mm}$. Similar to female (Fig. 2A-B). Head $1.5 \times$ as wide as high (Fig. 2B); tegula more brownish, bearing only a slightly purplish luster (Fig. 2C), metasoma more darkened (Fig. 2D): T2 and T3 largely dark purple; distal apex of T3 broken in the only known male specimen (Fig. 2F). Antennomeres P, F1, F2, F3 in the following proportions: $1.3,1.0,0.7,0.7 ; \mathrm{F} 1 \mathrm{1} / \mathrm{w}=2.0 ; \mathrm{OOL}=1.5 \mathrm{MOD} ; \mathrm{POL}=$ 1.6 MOD; MS = 1.0 MOD; S2 black spots (Fig. 2E) semicircular, anterior margin substraight, 1.6 MOD apart each other. Paramere (Fig. 9A) with inner margin rounded, distal apex flat; aedeagus wide, laterally not exposed.

\section{Distribution}

North and south Madagascar.

\section{Biology}

Unknown.

\section{Remarks}

According to Zimmermann (1956), a paratype female should be deposited at the Musée royal du Congo belge, Tervuren, Belgium (Royal Museum for Central Africa), however, no material of C. pumiloides was found (S. Hanot, Royal Museum for Central Africa, pers. com.). On the other hand, there is a female of $C$. pumiloides with a type label in NHMW, but it should not be the true paratype because the specimen is incongruent with the original description and the collection locality is Annarivo (= Antananarivo?) instead of Bekily, as given in the original description. In NHMW, we found similar erroneous type labels pinned with other chrysidids, including another Chrysidea: a specimen labelled as "type" of C. phoebe Zimmermann, 1956, which is conversely described on a single holotype specimen deposited in MNHN, without paratype designation.

Linsenmaier labelled a female from Antsingy (MNHN) as type of Chrysidea planipunctata, but it remained unpublished. The body color appears more greenish compared to the holotype female of C. pumiloides, however, other important morphological characters are indistinguishable. The color could be variable from more bluish, like a female from Behara (NHMW), to greenish, like a female from Antsingy and females and a male labeled "No. 66" (ELKU).

Chrysidea vazimba sp. nov. urn:1sid:zoobank.org:act:8EF8902C-9CD4-4AD0-B553-29D5CC1A0201

Figs 3-4, 9B

Chrysidea pumiloides - Bohart 1988: 130 (key, partim).

\section{Diagnosis}

Chrysidea vazimba sp. nov. is characterized by the combination of the following characters: TFC present; metatarsus basally light brown to yellowish; head wide, $1.3 \times$ as wide as high; distal margin of T3 with large, strong (female) or rounded (male) lateral teeth and rounded interval; MS $=0.7$ MOD; tegula with strong blue-green reflection; second metasomal tergum without microreticulate punctation.

\section{Etymology}

Chrysidea vazimba sp. nov. is named after the name of the first inhabitants of Madagascar, according to popular tradition. 


\section{Material examined}

\section{Holotype}

MADAGASCAR • O; “"Annanarivo/Madagaskar/Sikora [handwritten by Zimmermann]”; "Chrysidea/ pumiloides Zim./det. Zimmermann [handwritten by Zimmermann]"; "Type [red paper glued on the previous label]"; "Holotype 9 / Chrysidea vazimba Mita \& Rosa, 2019"; NHMW.

\section{Paratype}

MADAGASCAR • 1 đ̇; "Madagascar/Sikora"; "MUSEUM PARIS/MADAGASCAR/H DE SAUSSURE 1901"; "Chrysideal pumiloides/ ̋̂ Zimm./R M Bohart det [handwritten by Bohart]"; "Paratype $\widehat{\delta} /$ Chrysidea vazimba Mita \& Rosa, 2019"; MNHN.

\section{Description}

\section{Female}

\section{BODY LENGTH. $5.6 \mathrm{~mm}$.}

HEAD. Width $1.3 \times$ as wide as high. Scapal basin deep, transversely wrinkled and punctate, with sparsely located minute punctures. TFC present above scapal basin, substraight (Fig. 3B). Antennomeres P, F1,
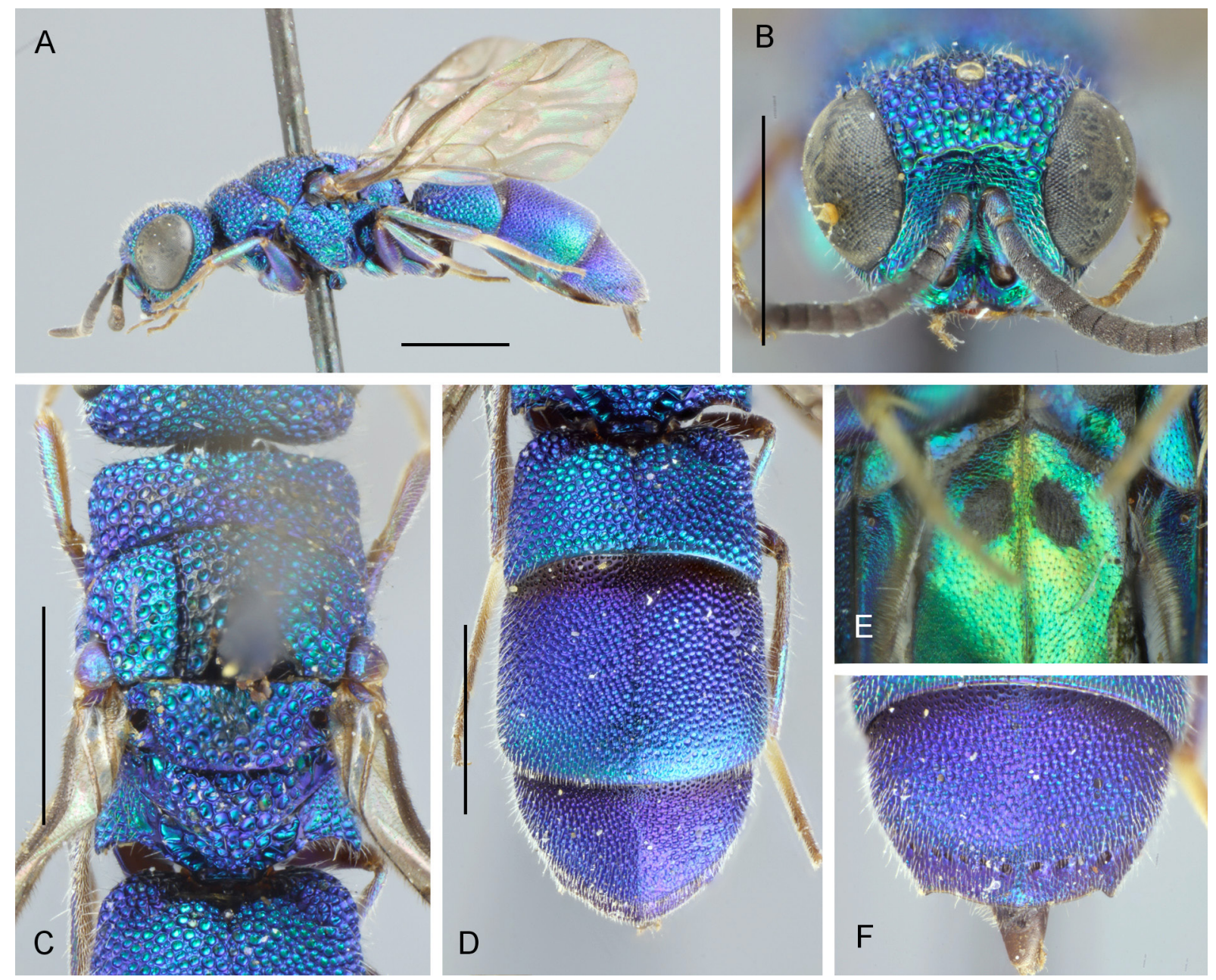

Fig. 3. Chrysidea vazimba sp. nov., holotype,, . A. Lateral habitus. B. Head. C. Mesosoma. D. Metasoma. E. Black spots on S2. F. T3. Scale bars $=1.0 \mathrm{~mm}$. 
F2, F3 in the following proportions: $1.3,1.8,1.2,1.2 ; \mathrm{F} 1 \mathrm{l} / \mathrm{w}=1.9 ; \mathrm{OOL}=1.8 \mathrm{MOD} ; \mathrm{POL}=2.1 \mathrm{MOD}$; $\mathrm{MS}=0.7 \mathrm{MOD}$; apical margin of clypeus almost straight, faintly concave; mandible edentate; basal width of mandible $=1.6 \mathrm{MOD}$. Brow with large, irregular and longitudinally contiguous punctures; punctures above TFC deeper, PD on brow: 0.5-0.7 MOD (Fig. 3B).

Mesosoma. Pronotal groove shallow and indistinct, extending $1 / 2$ length of pronotum. Notauli deep, complete; parapsidal lines indicated by smooth strip. Mesoscutellum weakly rounded. Metanotum humped (as in Fig. 4A), separated from mesoscutellum by deep furrow, large anteromedian pit present (Fig. 3C). Mesosoma entirely punctated by deep, coarse and irregularly sized punctures; pronotum mesoscutum, and mesoscutellum with densely located large and fewer small punctures: largest punctures 0.6 MOD. Episternal sulcus and scrobal sulcus distinct, formed by large foveae. Forewing with discoidal cell indistinct, outer veins faintly pigmented but apparently weaker and not tubular as other pigmented veins (Fig. 3A).

Metasoma. Median line faintly present on metasomal terga (Fig. 3D). Punctures on T1 0.2-0.4 MOD, densely located each other, interspaces with minute punctures; punctures on T2 and T3 smaller, 0.2-0.3 MOD, with interspaces smooth; pre-pit row area of T3 bulged; pit row distinct, with large and deep pits. Apex of T3 with a pair of acute lateral teeth, interval between teeth rounded (Fig. 3F). S2 (Fig. 3E) with black spots oval and medially separated by $0.6 \mathrm{MOD}$.
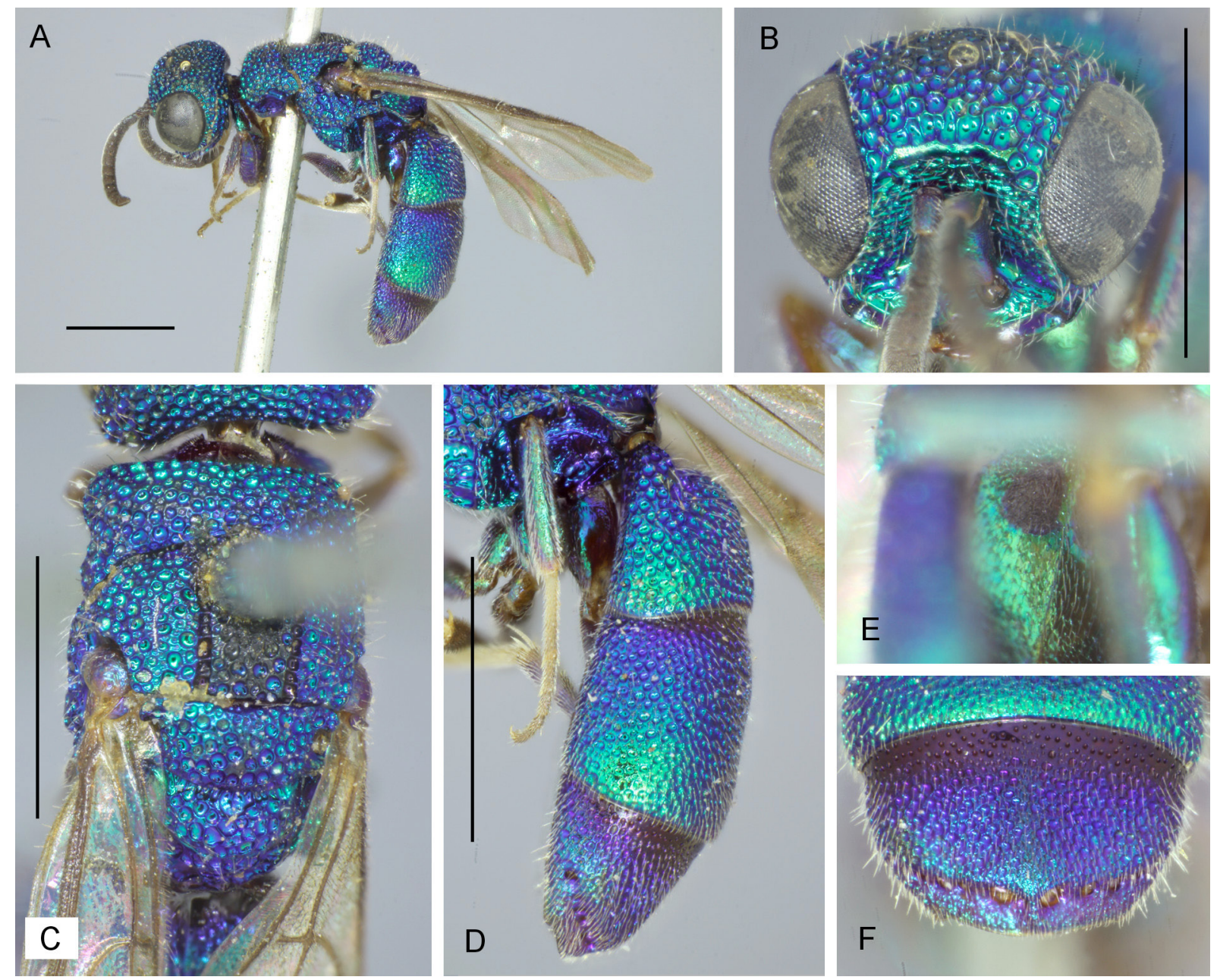

Fig. 4. Chrysidea vazimba sp. nov., paratype, $\overbrace{}^{\Uparrow}$. A. Lateral habitus. B. Head. C. Mesosoma. D. Metasoma. E. Black spots on S2. F. T3. Scale bars $=1.0 \mathrm{~mm}$. 
Coloration. Head metallic blue-green. Antenna dark brown with scape, pedicel and F1 metallic blue-green. Mandible testaceous, basal 1/3 metallic blue-green, apex reddish dark brown. Mesosoma metallic blue-green, with mesoscutum between notauli blackish, propodeum bearing purplish luster. Tegula brown with marked blue-green reflection. Legs greenish with purplish coxae, tarsi dark except metatarsus basally light brown to yellowish. T1 metallic blue-green, more greenish laterally and posteriorly, T2 metallic green-blue, more greenish posteriorly, behind posterior margin of T1 with black and purplish narrow bands; T3 basally blackish, apically metallic violet, bulged pre-pit row area bluish. Sterna metallic green.

\section{Male}

Body length $4.2 \mathrm{~mm}$. Similar to female (Fig. 4A-B) but different as follow: body slightly more greenish; lateral teeth on T3 rounded (Fig. 4D, F); S2 black spots (Fig. 4E) reniform; paramere with inner margin substraight (Fig. 9B); aedeagus strongly narrowed apically (Fig. 9B).

\section{Distribution}

Madagascar.

\section{Biology}

Unknown.

\section{Remarks}

The type locality name "Annanarivo" is ambiguous. It might indicate an area near Antananarivo, northeast of the capital city, or even a larger undefined area. The body color of Chrysidea vazimba sp. nov. is similar to that of C. pumiloides, but is easily distinguished by the presence of one TFC (Figs 3B, 4B) and humped metanotum. Morphological characters are rather similar to C. rhodopis Zimmermann, 1961; however, in $C$. vazimba sp. nov., interspaces among punctures on $\mathrm{T} 2$ are smooth and black spots on $\mathrm{S} 2$ are more rounded and more closely located each other (Figs 3E, 4E).

Chrysidea merina sp. nov. urn:1sid:zoobank.org:act:64E63FB6-4DD8-4180-8DC2-D6A7A6705AB0

Fig. 5

Chrysogona pumila - Buysson 1910: 125 (key, partim), 126.

Chrysidea pumiloides - Bohart 1988: 130 (key, partim).

\section{Diagnosis}

Chrysidea merina sp. nov. is characterized by the combination of the following characters: double TFC present; head wide, $1.4 \times$ as wide as high; distal margin of T3 with large, triangular lateral teeth and short median tooth, and interval faintly substraight; $\mathrm{MS}=0.8 \mathrm{MOD}$; tegula metallic blue-green, basally purplish; T2 without microsculpture.

\section{Etymology}

Chrysidea merina sp. nov. is named after the Merina people, the largest ethnic group in Madagascar.

\section{Material examined}

Holotype

MADAGASCAR • + ; "Madagascar"; "MUSEUM PARIS / MADAGASCAR / H DE SAUSSURE 1901"; "Chrysogona/pumila Klug/R. DU BUYSSON det. 19?? [handwritten by Buysson]"; 
"Chrysidea/pumiloides $q$ Zimm./R M Bohart det [handwritten by Bohart, two labels with the same information are pinned together]"; "Holotype + / Chrysidea merina Mita \& Rosa, 2019"; MNHN.

\section{Description}

\section{Female}

BODY LENGTH. $5.1 \mathrm{~mm}$.

HeaD. Width $1.4 \times$ as wide as high. Scapal basin deep, transversely wrinkled and outer margin punctate. Two TFC present above scapal basin and below anterior ocellus, sinuate (Fig. 5B). Antennomeres P, $\mathrm{F} 1, \mathrm{~F} 2, \mathrm{~F} 3$ in the following proportions: $1.5,1.8,1.3,1.5 ; \mathrm{F} 11 / \mathrm{w}=1.5 ; \mathrm{OOL}=2.3 \mathrm{MOD} ; \mathrm{POL}=2.3$ MOD; MS $=0.8 \mathrm{MOD}$; apical margin of clypeus weakly concave; mandible edentate; basal width of mandible $=1.5 \mathrm{MOD}$. Brow among the two TFC with large, irregular and contiguous foveate punctures; punctures above TFC deeper, PD on vertex 0.4-0.5 MOD (Fig. 5B).

Mesosoma. Pronotal groove shallow and indistinct, extending 3/4 length of pronotum. Notauli deep, complete; parapsidal lines indicated by smooth strip. Mesoscutellum almost flat. Metanotum rounded, not separated from mesoscutellum by deep furrow (Fig. 5A, C), large anteromedian pit present. Mesosoma
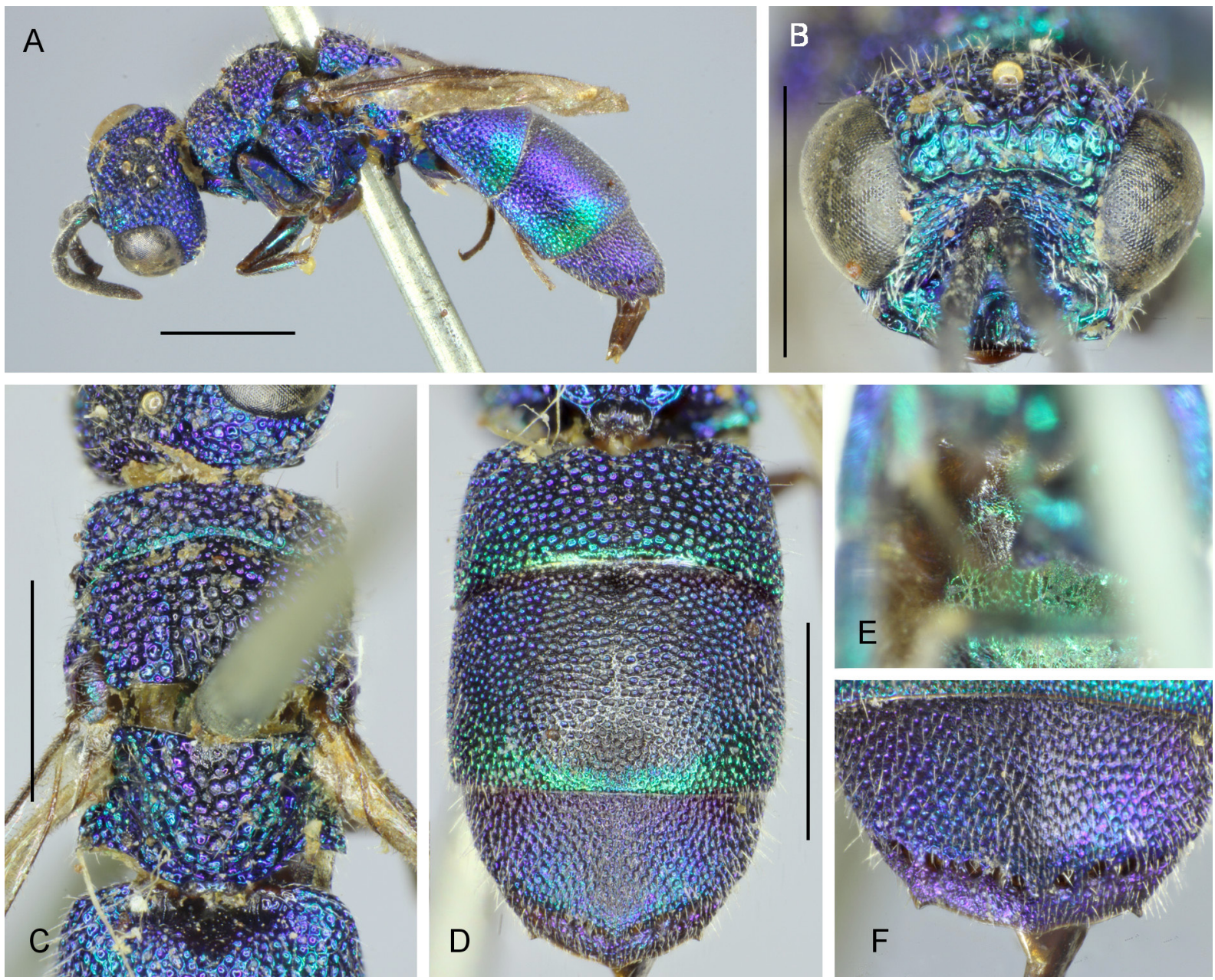

Fig. 5. Chrysidea merina sp. nov., holotype,, . A. Lateral habitus. B. Head. C. Mesosoma. D. Metasoma. E. Black spots on S2. F. T3. Scale bars $=1.0 \mathrm{~mm}$. 
entirely punctate by deep punctures; punctures on pronotum, mesoscutum, and mesoscutellum largely equal in size: largest punctures 0.6 MOD. Episternal sulcus and scrobal sulcus distinct, formed by large foveae. Forewing with discoidal cell enclosed by pigmented veins.

Metasoma. Median line scarcely visible on T1 and T2 (Fig. 5D). Punctures on T1 0.3-0.4 MOD, 0.20.5 PD apart, with smooth interspaces; punctures on T2 and T3 smaller, 0.2 MOD, with interspaces smooth only faintly microreticulate anteriorly and posteriorly; pre-pit row area of T3 not bulged; pit row distinct, with large and deep pits. Apex of T3 with a pair of lateral triangular teeth, interval between teeth substraight, short median tooth present (Fig. 5D, F). S2 black spots (Fig. 5E) oval and medially separated by 1.3 MOD.

Coloration. Head metallic blue, face and gena metallic blue-green with blue scapal basin, ocellar region blackish, vertex with violet luster. Antenna black with scape, pedicel metallic blue-green, F1 with faintly green luster. Mandible basally blackish, distally brown, basal 1/4 metallic green. Mesosoma metallic blue with violet luster, partly blue-green, surface between notauli blackish. Tegula metallic blue-green, basally purplish. Legs dark brown with strong green reflection except tarsi dark brown. Metasomal terga metallic blue, blackish medially, posterior margin of T1 and T2 greenish, T3 with violet luster. Sterna metallic green.

\section{Male}

Unknown.

\section{Distribution}

Madagascar.

\section{Biology}

Unknown.

\section{Remarks}

The color of Chrysidea merina sp. nov. is similar to that of C. pumiloides; however, it is easily distinguished from the latter by the presence of a double TFC (Fig. 5B), the forewing with discoidal cell enclosed by pigmented veins and the median tooth on T3. A similar median tooth is present in $C$. dido Zimmermann, 1956, but it has discoidal cell framed by only weakly pigmented veins. Following characters are useful to distinguish $C$. merina sp. nov. from $C$. dido: bluish body color; small and dense punctures on T2 (Fig. 5D); median tooth on T3 very small and interval between lateral and median tooth substratight (Fig. 5F). The body color of $C$. dido is metallic green, punctures on $\mathrm{T} 2$ are larger and sparser, interval between lateral and median tooth excavated.

Chrysidea phoebe Zimmermann, 1956

Figs 6-7, 9C

Chrysidea phoebe Zimmermann, 1956: 151

Chrysidea phoebe - Zimmermann 1961: 320 (catalog). — Bohart 1988: 130 (key, partim). - Kimsey \& Bohart 1991: 314 (catalog). — Madl 2008: 83 (catalog). — Azevedo et al. 2010: 830 (catalog).

Chrysidea pumiloides - Zimmermann 1961: 320 (catalog). — Bohart 1988: 130 (key, partim). — Kimsey \& Bohart 1991: 314 (catalog). — Madl 2008: 83 (catalog). — Azevedo et al. 2010: 830 (catalog). 


\section{Material examined}

\section{Holotype}

MADAGASCAR • +; "MNHN, Paris/EY25667”; "MUSÉUM PARIS”; "Madagascar: Bekily/XI 1943 / A. Seyrig"; "Chrysidea / phoebe Zimm. / det. Zimmermann/Type! [handwritten by Zimmermann]”; "o Chrysidea/phoebe/Zimmermann/Holotype [handwritten on red card]"; MNHN.

\section{Other material}

MADAGASCAR • 1 O; "MADAGASCAR/BEHARA"; "MUSÉUM PARIS/I. 38/A. SEYRIG"; "Chrysidea/phoebe Zimm./det. Zimmermann [handwritten by Zimmermann on white card]"; "Type [red paper glued on the previous label]"; NHMW • 1 ơ; "Madagascar/Sikora"; "MUSEUM PARIS / MADAGASCAR/H. DE SAUSSURE 1901"; "Chrysidea/pumiloides / § Zimm. [handwritten by Bohart]"; MNHN.

\section{Diagnosis}

Chrysidea phoebe is characterized by the combination of the following characters: metatarsus paler, yellowish to testaceous; TFC present; head wide, $1.2-1.3 \times$ as wide as high; MS $=0.6-0.8 \mathrm{MOD}$; tegula metallic green; T2 with interspaces among punctures distinctly (female) or weakly (male) microreticulate; distal margin of T3 with large, triangular lateral teeth and distal apex angulated, interval between median angle and lateral tooth substraight; paramere with inner margin weakly expanded, narrowed apically.

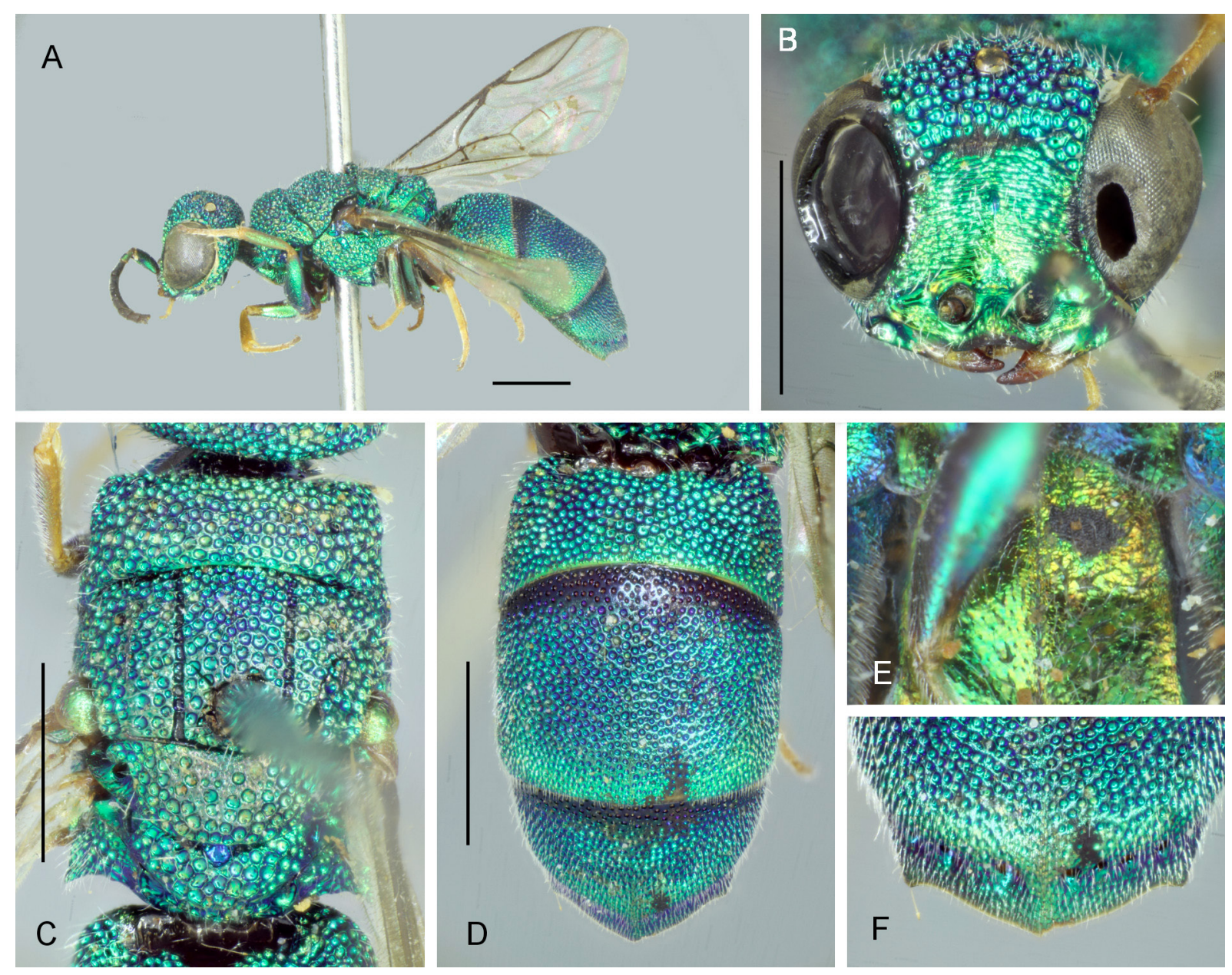

Fig. 6. Chrysidea phoebe Zimmermann, 1956. A-D, F. Holotype, ․ A. Lateral habitus. B. Head. C. Mesosoma. D. Metasoma. E. Female from Behara, black spots on S2. F. T3. Scale bars $=1.0 \mathrm{~mm}$. 


\section{Description}

\section{Female}

Body LENGTH. $6.2 \mathrm{~mm}$.

HEAD. Width $1.2 \times$ as wide as high. Scapal basin deep, transversely wrinkled and outer margin punctate. TFC present above scapal basin, sinuate (Fig. 6B); second irregular TFC present but indistinct between midocellus and TFC (Fig. 6B). Antennomeres P, F1, F2, F3 in the following proportions: 1.9, 2.3, 1.8, 1.3; F7-11 missing in holotype; $\mathrm{OOL}=1.7 \mathrm{MOD} ; \mathrm{POL}=2.3 \mathrm{MOD} ; \mathrm{MS}=0.6 \mathrm{MOD}$; apical margin of clypeus weakly concave; mandible edentate; basal width of mandible $=1.3 \mathrm{MOD}$. Brow with large, irregular and longitudinally contiguous punctures; punctures between the two TFC deeper, irregular, and continuous (Fig. 6B), PD on vertex 0.3-0.5 MOD.

Mesosoma. Pronotal groove shallow and indistinct, extending $4 / 5$ length of pronotum. Notauli deep, complete; parapsidal lines indicated by smooth strip. Mesoscutellum almost flat. Metanotum weakly producing posteriorly (Fig. 6A), separated from mesoscutellum by deep furrow and large anteromedian pit (Fig. 6C). Mesosoma entirely covered with large deep punctures and small shallow punctures: largest punctures 0.6 MOD; mesoscutellum medially with impunctate area, interspaces among punctures microsculptured (Fig. 6C). Episternal sulcus and scrobal sulcus distinct, formed by large foveae. Forewing with discoidal cell framed by nebulous veins, not enclosed by pigmented veins (Fig. 6A).

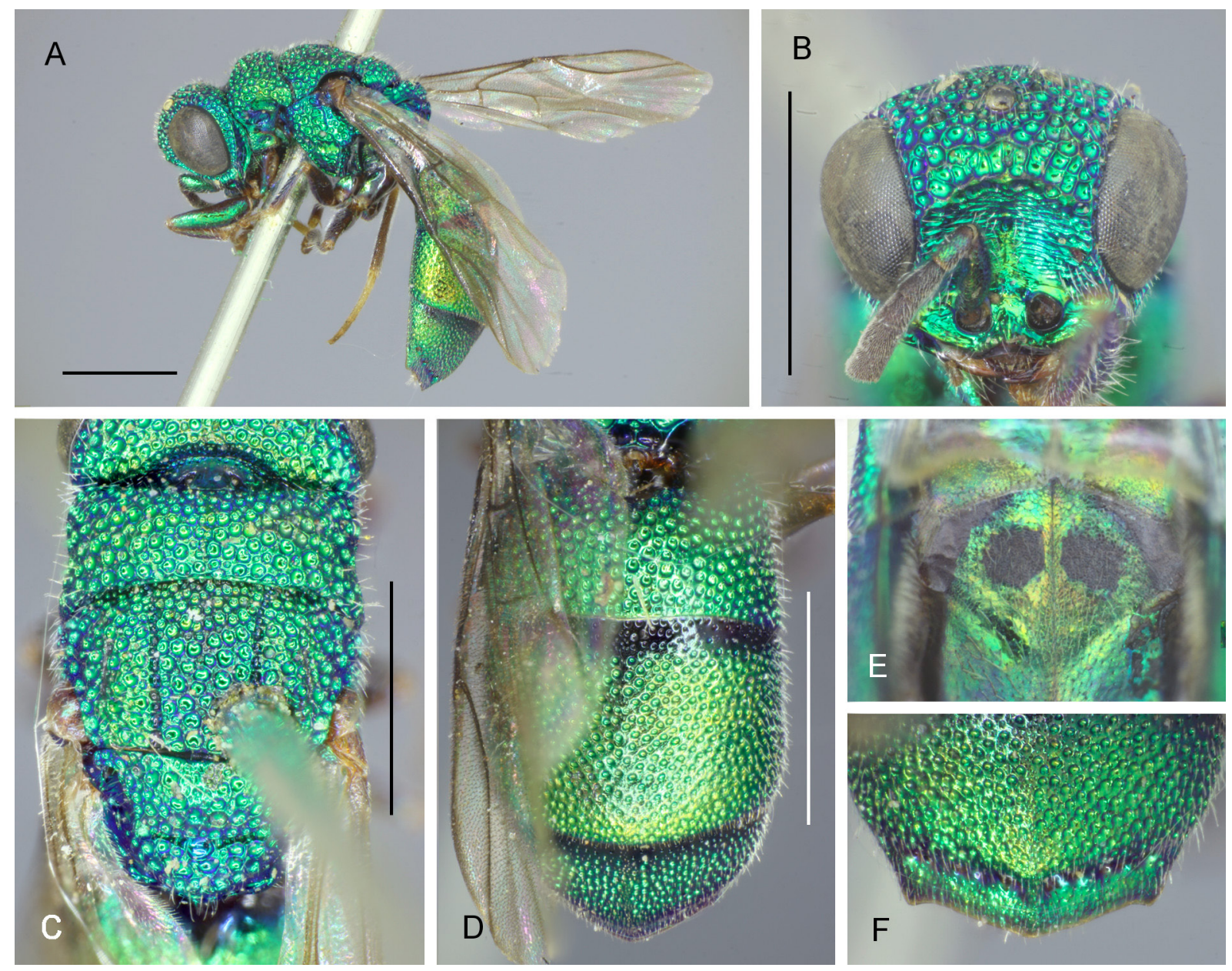

Fig. 7. Chrysidea phoebe Zimmermann, 1956, §. A. Lateral habitus. B. Head. C. Mesosoma. D. Metasoma. E. Black spots on S2. F. T3. Scale bars $=1.0 \mathrm{~mm}$. 
Metasoma. Faint median line present on T1 (Fig. 6D). Punctures on T1 0.3-0.5 MOD, 0.1-0.2 PD apart, with smooth interspaces; punctures on T2 smaller, 0.2-0.3 MOD, 0.2 PD apart, with interspaces microreticulate; median line indistinct (holotype) or distinct (a female in NHMW); pre-pit row area of T3 not bulged; pit row distinct, with large and deep pits. Apex of T3 with a pair of lateral triangular teeth; distal apex angulated (Fig. 6F); interval between lateral tooth and median angle substraight. S2 black spots (Fig. 6E) oval, 0.5 MOD apart each other (metasomal sterna missing in holotype).

Coloration. Head and mesosoma metallic green or blue-green with blue or purplish luster, ocellar region more bluish. Antenna black with scape, pedicel metallic green. Mandible medially testaceous, distally dark brown, basal $1 / 2$ metallic green. Tegula metallic green; deep anteromedian pit on metanotum metallic blue. Legs metallic green or blue-green except tarsi entirely yellowish (Fig. 6A). Metasomal terga metallic green or blue-green with blue luster; metasomal sterna metallic green with golden luster (holotype lacks sterna).

\section{Male}

Body $4.7 \mathrm{~mm}$. The single known specimen lacks F5-F11. Similar to female (Fig. 7A-B, F), but different as follow: body greenish, metasoma metallic green with faint golden luster (Fig. 7D), tarsi dark testaceous, only metabasitarsus yellowish; head $1.3 \times$ as wide as high, upper TFC more distinct (Fig. 7B), MS =0.8 MOD; interspaces among punctures on mesoscutellum smooth (Fig. 7C); tarsi light brown with metabasitarsus testaceous (Fig. 7A); punctures on metasoma sparser, 0.2-0.3 PD apart on T2; S2 black spots large, rounded, medially separated by 0.4 MOD (Fig. 7E); paramere with inner margin weakly expanded, narrowed apically (Fig. 9C); aedeagus narrowed apically (Fig. 9C).

\section{Distribution}

Southern Madagascar.

\section{Biology}

Unknown.

\section{Remarks}

Chrysidea phoebe is similar to C. phragmiticola Zimmerman, 1961. The T3 distal apex in C. phoebe is distinctly angulated and the interval between the median angle and a lateral tooth is substraight (Figs 6F, 7F); on the other hand, the posterior margin is rounded and the median angle is absent in C. phragmiticola. The body color of both species is basically metallic green, but metabasitarsus of C. phoebe is yellowish (Figs 6A, 7A), non-metallic green as in C. phragmiticola. A female in NHMW is considered to be non-type material, even if it has a type label, because no type was designated other than the holotype deposited in MNHN (Zimmermann, 1956).

Chrysidea rioae sp. nov.

urn:1sid:zoobank.org:act:325DDA9D-4783-40F8-815F-A1D95A46EC25

Figs 8, 9D

\section{Diagnosis}

Chrysidea rioae sp. nov. is characterized by the combination of the following characters: TFC absent; head narrow, $1.8 \times$ as wide as high; distal margin of T3 with large, triangular lateral teeth and area between faintly concave medially; MS 1.2 MOD; tegula metallic blue; second metasomal tergum with interspaces among punctures microreticulate; paramere narrowed, triangular; aedeagus wide, laterally not expanded. 


\section{Etymology}

The specimen was collected during the field trip in Madagascar from January to February 2018. After that, the holotype was displayed at the summer exhibition of the National Museum of Nature and Science, Tokyo, Japan from July to October 2018. The species is named after Ms Rio Matsushima, a girl who visited the exhibition and heartily encouraged our study on this tiny blue wasp.

\section{Material examined}

\section{Holotype}

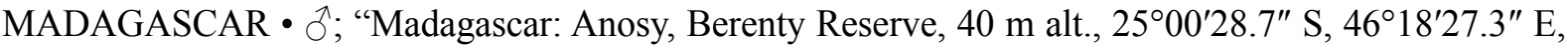
7-12. II. 2018, Yellow pan trap, T. Mita leg."; "Holotype $\widehat{~} /$ Chrysidea rioae Mita \& Rosa, 2019"; ELKU.

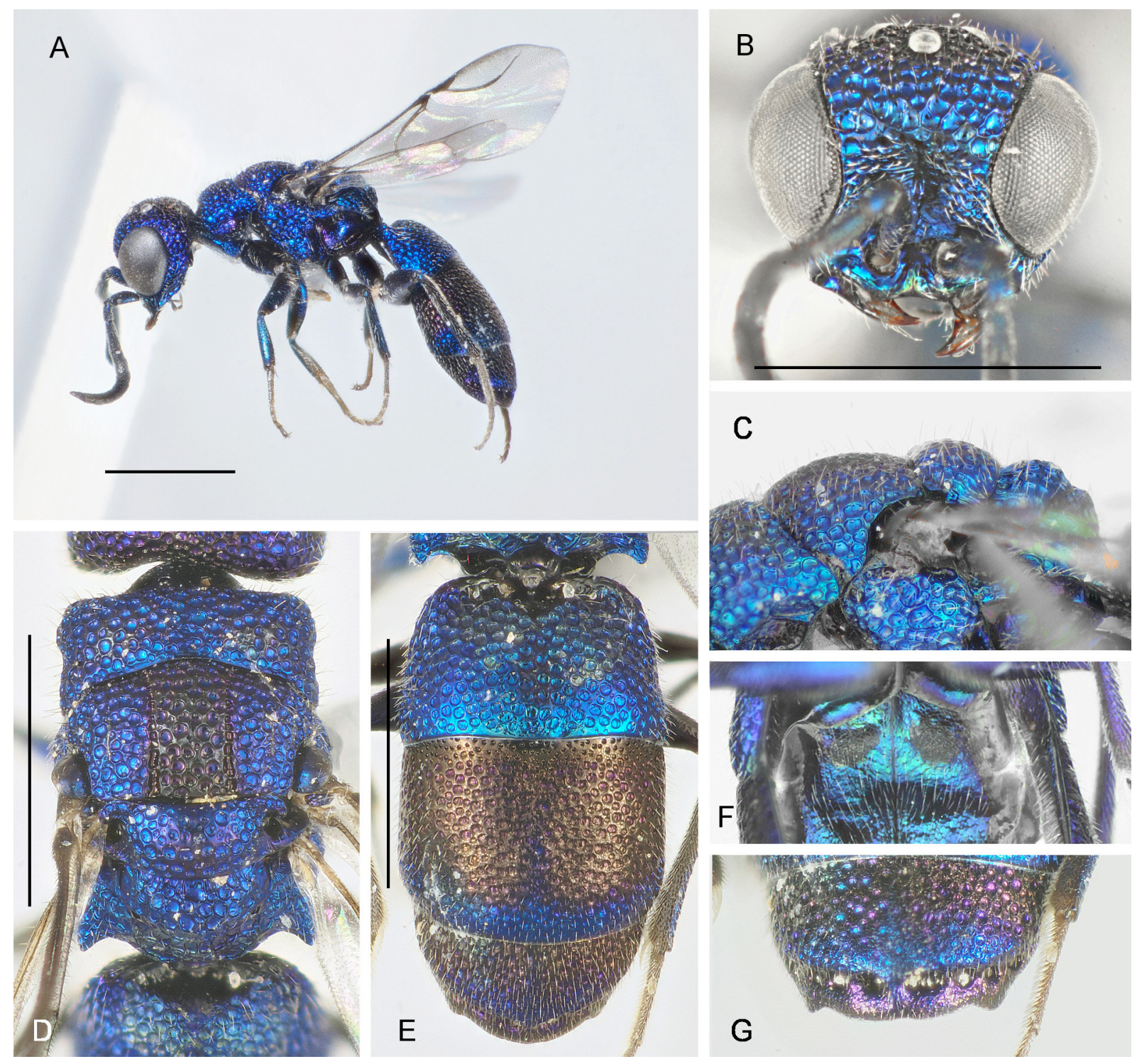

Fig. 8. Chrysidea rioae sp. nov., holotype, $\widehat{\partial}$. A. Lateral habitus. B. Head. C. Mesoscutum, mesoscutellum and metanotum in lateral view. D. Mesosoma. E. Metasoma. F. Black spots on S2. G. T3. Scale bars = $1.0 \mathrm{~mm}$. 


\section{Description}

Male

Body LeNGTH. $3.8 \mathrm{~mm}$.

HEAD. Width $1.8 \times$ as wide as high. Scapal basin deep, transversely wrinkled and punctate with sparsely located minute punctures. TFC absent (Fig. 8B). Antennomeres P, F1, F2, F3: 1.2 : $1.3: 1.2$ : 0.8 ; $\mathrm{F} 1 \mathrm{l} / \mathrm{w}=1.6 ; \mathrm{OOL}=1.7 \mathrm{MOD} ; \mathrm{POL}=2.0 \mathrm{MOD} ; \mathrm{MS}=1.2 \mathrm{MOD}$; apical margin of clypeus almost straight, faintly concave; mandible edentate, basally with a deep notch; basal width of mandible = 1.0 MOD. Brow with large, irregular and contiguous foveate punctures; PD on brow: 0.3-0.6 MOD (Fig. 8B).

Mesosoma. Pronotal groove shallow, extending $4 / 5$ length of pronotum. Sublateral carina indistinct. Notauli deep, complete; parapsidal lines indicated by smooth strip. Mesoscutellum humped. Metanotum humped (Fig. 8C), separated from mesoscutellum by deep furrow, large anteromedian pit present but shallow as other marginal punctures (Fig. 8D). Mesosoma entirely punctate by deep, coarse and irregularly sized punctures; pronotum and mesoscutum with densely located, large and fewer small punctures: largest punctures 0.5 MOD; punctures on mesoscutellum sparser than those on mesoscutum, with smooth interspaces. Episternal sulcus indicated by shallow depression; scrobal sulcus formed by a row of deep and large foveae. Forewing with discoidal cell framed by nebulous veins, outer veins almost invisible (Fig. 8A).

Metasoma. Median carina faint on terga (Fig. 8E). Punctures on T1 0.3-0.4 MOD, densely located each other, with smooth interspaces; punctures on T2 and T3 smaller, 0.2-0.3 MOD, with interspaces faintly microreticulate; pre-pit row area of T3 not bulged; pit row distinct, with large and deep pits. Apex of T3 (Fig. 8G) with a pair of lateral dully teeth, interval between teeth rounded, faintly concave medially. S2 black spots (Fig. 8F) transverse, oval and medially separated by 0.8 MOD. Distal apex of paramere narrowed, triangular (Fig. 9D); aedeagus wide, laterally not expanded (Fig. 9D).

Coloration. Head metallic blue, around ocellar region blackish. Clypeus partly greenish. Antenna black with scape, pedicel and F1 metallic blue. Mandible black, basal margin metallic blue, distal half brown. Mesosoma metallic blue, with mesoscutum between notauli blackish. Tegula metallic blue. Legs metallic blue, with dark brown tarsi. T1 metallic blue, T2 black with violet luster except posterior margin metallic blue; T3 basally blackish, apically metallic blue, with violet luster. Sterna dark metallic blue.

\section{Female}

Unknown.
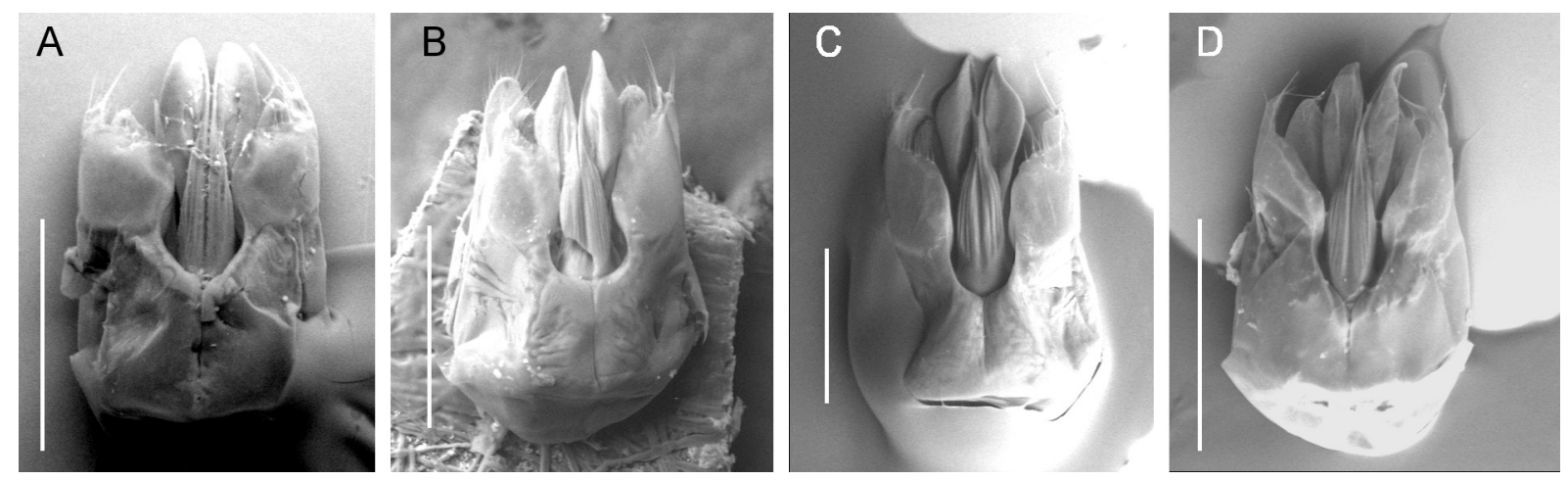

Fig. 9. Male genitalia of Chrysidea spp. A. C. pumiloides Zimmermann, 1956. B. C. vazimba sp. nov. C. C. phoebe Zimmermann, 1956. D. C. rioae sp. nov. Scale bars $=0.25 \mathrm{~mm}$. 


\section{Distribution}

Southern Madagascar (Anosy).

\section{Biology}

Unknown.

\section{Remarks}

The holotype was collected in a yellow pan trap set in the dry forest along the Mandrare River. Chrysidea rioae sp. nov. is similar to C. pumiloides, in the smaller body size, the general habitus and the microreticulation on the second metasomal tergum; however, in C. rioae sp. nov. the base of punctures on the mesosoma is deep and rounded (Fig. 8D); the metanotum is humped (Fig. 8C) and a large anteromedian pit is present; the distal apex of paramere is narrowed (Fig. 9D). In C. pumiloides, the base of punctures is shallow and flat (Figs 1C, 2C), the metanotum is rounded (Fig. 1A), the anteromedian pit is absent, and the distal apex of the paramere is flat (Fig. 9A).

\section{Key to species of Chrysidea in Madagascar}

1. Discoidal cell framed by pigmented strong veins

- Discoidal cell framed by faint nebulous veins

2. T3 with a median small tooth (Fig. 5F), double TFC

C. merina sp. nov.

- T3 without median small tooth, interval between lateral teeth rounded (Fig. 3F), single or absent TFC

3. T2 medial punctures as large as, or larger than those on mesoscutum

- $\quad \mathrm{T} 2$ medial punctures smaller than those on mesoscutum

C. bellula Guérin-Méneville, 1842

T2 medial punctures smaller than those on mesoscutum ....

C. agnata Zimmermann, 1956

4. Lateral margin of mesoscutum adjacent to tegula strongly raised ...C. bicallosa (du Buysson, 1910)

- Lateral margin of mesoscutum adjacent to tegula not raised, at most indicated by rows of deep punctures

5. T3 medially subtruncate, metanotum produced posteriorly into a point

C. zimmermanni Bohart, 1988

- T3 variable, not subtruncate, metanotum rounded or humped, not produced posteriorly into a point

6. MS about 2.5 MOD, and subparallel, lower face expanded

C. bucculenta (Mocsáry, 1908)

- MS about 1.0 MOD or shorter, convergent

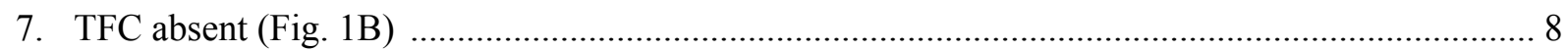

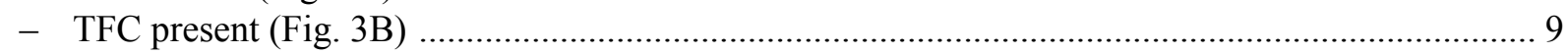

8. Mesoscutellum and metanotum humped (Fig. 8A, C), punctures on mesosoma deep and its base rounded; (male) paramere narrowed apically (Fig. 9D)

C. rioae sp. nov.

- Mesoscutellum almost flat and metanotum rounded (Figs 1A, 2A), punctures on mesosoma shallow and its base flat; (male) distal apex of paramere flat (Fig. 9A) 
9. T3 with a median tooth or angle, not rounded apicomedially (Fig. 5F) ……............................ 10

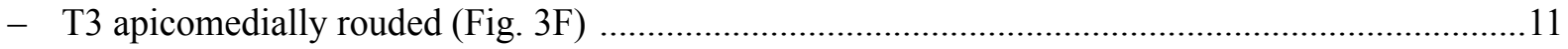

10. Pronotum with developed sublateral carina, $\mathrm{T} 3$ with a distinct median tooth, interval between lateral tooth and median tooth concave ............................................................ . dido Zimmermann, 1956

- Pronotum without sublateral carina, T3 apicomedially angulate, not forming a median tooth, interval between lateral tooth and median angle substraight ......................... C. phoebe Zimmermann, 1956

11. Mesosoma elongate, in dorsal view fully twice as long as wide at pronotum, metasomal terga extensively coppery gold

C. aurata (Bischoff, 1910)

- Mesosoma not distinctly elongate, in dorsal view at most $1.7 \times$ as long as wide at pronotum, base color of metasomal terga metallic green or blue, at most posterior part of terga

12. T3 extensively coppery, anterior ocellus not larger than some areolae below it

C. brooksi Bohart, 1988

- T3 not extensively coppery, at most metallic green with golden luster, size of areolae below anterior ocellus variable

13. Maximum diameter of black spots on $\mathrm{S} 2$ smaller than midocellus

.C. phragmiticola Zimmermann, 1961

- Black spots on S2 larger than anterior ocellus

14. Pronotum with developed sublateral carina (as in Trichrysis); metatarsi metallic; T3 with strong median carina, lateral teeth acute and large; on T3 interspaces among punctures anteromedially 1.0-2.0 PD apart

C. antiope Zimmermann, 1961

- Pronotum without sublateral carina; metatarsi non-metallic, blackish or testaceous; T3 without strong median carina, at most faintly indicated, lateral teeth blunt and short; punctures on T3 denser, almost subcontiguous

15. Lateral area of mesoscutum with a longitudinal row of distinctly larger and deeper punctures, T3 with large and deep pits of the pit row, black spots on S2 1.5 MOD apart

C. rhodopis Zimmermann, 1961

- Lateral area of mesoscutum without a row of distinctly large punctures, T3 with small and shallow pits of the pit row, black spots on S2 0.6 MOD apart

C. vazimba sp. nov.

\section{Discussion}

We examined the holotype of Chrysidea pumiloides and voucher specimens identified as C. pumiloides. As a result, four different species were recognized: $C$. pumiloides and three different species including two new species, $C$. merina sp. nov. and $C$. vazimba sp. nov. The other new species, $C$. rioae sp. nov. is the third species of the genus Chrysidea without TFC. The finding of three new species from the limited number of specimens implies higher species diversity of Malagasy Chrysidea.

Specimens of Chrysidea are not so abundant in museum collections, especially in recently collected material. Among them, the collections of Seyrig and Saussure, which were amassed around 50-100 years ago, greatly contribute the current understanding of Malagasy fauna. Compared with the past, their habitat should be restricted because more than $80-90 \%$ of Madagascar's original vegetation is estimated to be destroyed (Fisher \& Robertson 2002; Ichino 2007). Recently the decline of large trees and the forest drying have been observed in the Berenty reserve, the type locality of $C$. rioae sp. nov. (Ichino 2007). The hosts of the five species treated in this study are unknown, this is actually the case with most species of Chrysididae. Further field investigation is needed to understand their life history and habitat requirements. 


\section{Acknowledgments}

We are grateful to C. Villemant (MNHN), A. Touret-Alby (MNHN), D. Zimmermann (NHMW), H. Zettel (NHMW), M. Vizek (NHMW), M. Madl (NHMW) and S. Hanot (Royal Museum for Central Africa, Tervuren, Belgium) for their cooperation and assistance in the study of chrysidid specimens deposited in the museum collections. We are also grateful to K. Martynova and an anonymous reviewer for their useful comments and suggestions. TM appreciates B. Andriamihaja (MICET) and local authorities for organizing our field work in Madagascar, research and export permits. The field trip was conducted for the special exhibition organized by the National Museum of Nature and Science (NMNS), the Yomiuri Shimbun and Fuji Television Network, Inc. TM is indebted to A. Andrianaja, M. Maruyama (Kyushu University Museum) and S. Kakizoe (ELKU) for their help on this trip, and to S. Nomura (NMNS), U. Jimbo (NMNS) and T. Ide (NMNS) for providing the opportunity to conduct this study.

\section{References}

Azevedo C., Madl M. \& Olmi M. 2010. A Catalogue of the Bethylidae, Chrysididae, Dryinidae, Embolemidae, Sclerogibbidae and Scolebythidae (Hymenoptera: Chrysidoidea) of the Malagasy Subregion. Linzer biologische Beiträge 42: 845-918.

Bohart R.M. 1988. New species of Chrysidea and a key to the Madagascan species (Hymenoptera: Chrysididae). Journal of the Entomological Society of South Africa 51 (1): 129-137.

Buysson R. du. 1910. Les Chrysidides de Madagascar (Hym.). Revue d'Entomologie 28: 123-134.

Fisher B.L. \& Robertson H.G. 2002. Comparison and origin of forest and grassland ant assemblages in the high plateau of Madagascar (Hymenoptera: Formicidae) 1. Biotropica 34: 155-167.

https://doi.org/10.1111/j.1744-7429.2002.tb00251.x

Ichino S. 2007. The state and problems of Lemur conservation in the Berenty reserve, southern Madagascar. Asian and African Area Studies 6 (2): 197-214.

Kimsey L.S. \& Bohart R.M. 1991 (1990). The Chrysidid Wasps of the World. Oxford University Press, New York.

Madl M. 2008. New records of the family Chrysididae (Hymenoptera) from Madagascar. Entomofauna 29 (5): 81-92.

Pauli T., Castillo-Cajas R.F., Rosa P., Kukowka S., Berg A., van den Berghe E., Fornoff F., Hopfenmüller S., Niehuis M., Peters R.S., Staab M., Strumia F., Tischendorf S., Schmitt T. \& Niehuis O. 2019. Phylogenetic analysis of cuckoo wasps (Hymenoptera: Chrysididae) reveals a partially artificial classification at the genus level and a species-rich clade of bee parasitoids. Systematic Entomology 44 (2): 322-335. https://doi.org/10.1111/syen.12323

Rosa P. \& Xu Z-f. 2015. Contribution to the genus Chrysidea Bischoff, 1913 from China, with description of a new species (Hymenoptera, Chrysididae). Zootaxa 4040: 465-468.

https://doi.org/10.11646/zootaxa.4040.4.6

Rosa P., Wei N-S., Feng J. \& Xu Z-f. 2016. Revision of the genus Trichrysis Lichtenstein, 1876 from China, with description of three new species (Hymenoptera, Chrysididae). Deutsche entomologische Zeitschrift 63 (1): 109-136. https://doi.org/10.3897/dez.63.7347

Sann M., Niehuis O., Peters R.S., Mayer C., Kozlov A., Podsiadlowski L., Bank S., Meusemann K., Misof B., Bleidorn C. \& Ohl M. 2018. Phylogenomic analysis of Apoidea sheds new light on the sister group of bees. BMC Evolutionary Biology 18: 71. https://doi.org/10.1186/s12862-018-1155-8

Zimmermann S. 1956. Contribution à l'étude des Chrysidides de Madagascar (Hymenoptera). Mémoires de l'Institut scientifique de Madagascar, Série E 7: 141-165. 
Zimmermann S. 1961. Zweiter Beitrag zur Kenntnis der Chrysididen Madagascars (Hymenoptera). Mémoires de l'Institut scientifique de Madagascar, Série E 12: 297-321.

Manuscript received: 6 May 2019

Manuscript accepted: 18 July 2019

Published on: 8 October 2019

Topic editor: Gavin Broad

Desk editor: Pepe Fernández

Printed versions of all papers are also deposited in the libraries of the institutes that are members of the EJT consortium: Muséum national d'Histoire naturelle, Paris, France; Meise Botanic Garden, Belgium; Royal Museum for Central Africa, Tervuren, Belgium; Royal Belgian Institute of Natural Sciences, Brussels, Belgium; Natural History Museum of Denmark, Copenhagen, Denmark; Naturalis Biodiversity Center, Leiden, the Netherlands; Museo Nacional de Ciencias Naturales-CSIC, Madrid, Spain; Real Jardín Botánico de Madrid CSIC, Spain; Zoological Research Museum Alexander Koenig, Bonn, Germany; National Museum, Prague, Czech Republic. 